KERTTU TAN NER

\title{
Kehtolaulut suomalaisessa lyriikassa
}

Lyriikkamme kehtolaulujen historia yltää niin etäälle entisaikaan kuin runouttamme yleensä voidaan seurata. Vanhalla runomitalla sepitetyissä tuutulauluissa on kauneinta runollisuutta mitä kansanrunoudessamme on talletettuna. Niissä muinaisajan äidit laulavat lapselleen univirttä kutsuen häntä hellillä hyväilynimillä. Lapselle toivotetaan parempaa osaa elämässä kuin vanhemmat itse ovat saaneet. Useissa lauluissa on vielä toivomus, että lapsesta varttuisi tuki ja turva tuudittajalle. Koska tyttölapsen kohtalona on joutua pois kotoaan, tuntuu äidistä melkein kuin tyhjää tuutisi, toiselle toimittaisi. Poikalapsen kohdalla asia on sen sijaan toinen:

Ken se tuutii poikalasta, sepä totta torjuttavi; ken se tuutivi tytärtä, se vaan tyhjeä tekevi.

Toisaalta kuitenkin naimaton tytär on talon häpeä ja äiti kiirehtii jo kehtolauluissa toivomaan tyttärelleen naimaonnea, toivoopa vielä, että hänet "sitte nuorra naitaisi, / vihantana vietäisi". Parhaimpia sulhasehdokkaita tyttövauvalle ovat "kirjankantajat", siis oppineet, porvarit ja kauppamiehet. Varakkuutta täytyy olla, koska se takaa tyttärelle huolettoman tulevaisuuden, saattaapa hän vielä tulla "vanhemmankin varaksi". Rengit, palkkalaiset ja sotilaat toivotetaan loitolle tyttären näköpiiristä. Heillä on hyvin epävakainen tulevaisuus eikä ollenkaan varallisuutta: "Huolet huovilla tupana, / miekan ponnet porstuana, / saapukka salitupana." Samasta syystä toivotaan, ettei poikalapsesta tulisi sotilasta, "surman suupalasta". Poikavauvankin tulevasta elämänkumppanista äiti jo näin varhain on huolissaan ja toivoo hänelle kunnon emäntää. Mutta siinä tapauk- 
sessa, ettei sopivaa kumppania löydy, on "parempi yksin öitä olla, / kuin kahen pahan keralla, / viien, kuuen kunnottoman".

Maallisen elämän mukavuus ja turvattu tulevaisuus ovat siis muinaisajan äidin ensimmäisiä toivomuksia lapselleen jo hänen pienokaiselle laulamissaan kehtolauluissa. Mutta äiti ei voi välttyä pessimistisistäkään tunnelmista. Hän tietää myös, että hartaimmatkaan toivomukset eivät pysty ehdottoman varmasti takaamaan lapselle onnellista tulevaisuutta. Peläten, että elämä kuitenkin koettelee hänen lastansa liian kovasti, äiti toivottaa pikkuisensa usein jo sylivauvana Manan kartanoihin, Tuonen tuville. Näissä pessimistissävyisissä tuutulauluissa äiti paljastaa myös oman väsymyksensä elämään. Varsinkin tyttölasta hän usein toivottelee kuolemaan, sillä "parempi tytön Tuonelassa, / kuin kehnon miehen kainalossa". ${ }^{1} \mathrm{Kan}-$ sanihmisillä oli jo muutenkin se käsitys, että varhainen kuolema oli parasta lapselle. Tätä kuvastaa jo sananparsikin: 'Taivaas lapsen koto on." 2 Erikoisen kauniissa, runollisessa muodossa on Tuonelaajatus pienessä kehtolaulussa "Tuuti lasta Tuonelahan":

Tuuti, tuuti tummaistani,
tummaisessa tuutusessa,
tummaisella tuutijalla,
tummaisen tuvan sisässä!
Tuuti lasta Tuonelahan,
lasta lautojen sylihin,
alla nurmen nukkumahan,
maan alle makoamahan,
Tuonen lasten laulatella,
Manan neitojen piellä!
Tuonen tuutunen parempi,
Manan kätkyt kaunoisampi,
etevämmät Tuonen eukot,
paremmat Manan miniät,
tupa suuri Tuonelassa,
Manalla majat avarat.

1 Eeva Louko, Äidin toiveita kansamme kehtolauluissa. Kal.seur. vuosik. 37. S. 129 .

2 Elsa Enäjärvi-Haavio, Lyyrilliset laulut, teoksessa Martti Haavio, Suo malaisen muinaisrunouden maailma. Porvoo 1935. S. 169. 
Tämä kuusitoista säettä käsittävä tummavireinen pikku laulu on tunnetuin kansanomaisella runomitalla lauletuista pessimistissävyisistä kehtolauluista. Entisajan äiti toivoo siinä lapselleen parhaan olon, mitä voi ajatella. Runon melankolinen viritys on hyvin sopusoinnussa äidin mielentilan kanssa. Mutta runo on myös harvinaisen keskitetty, siinä ei ole laverteluja eikä korusanoja. Laulu on lähtenyt suoraan sydämen hartaasta toiveesta. Tästä kauniista kehtolaulusta yltää suora linja läpi vuosisatojen nykyiseen suomalaiseen taiderunouteen asti. Sen surumielinen kuolemanikävöinti on siirtynyt Aleksis Kiven, Eino Leinon, Kaarlo Sarkian ja monen muun lyyrikon kehtorunoihin. Eri sukupolvet ilmaisevat sen omalla tavallaan, mutta ajatus pysyy samana.

1600- ja 1700-1ukujen kehtolaulut muistuttavat paljon sekä runomitaltaan että sisällöltään kansanomaisia tuutulauluja. Niinpä Messukylän kirkkoherran, Henrikki Liliuksen "Kehto-Runot, joilla yxi Christillinen äiti wähäistä lastansa nucutta taita", vuodelta 1728 , alkaa aivan kansanrunon tapaan, "Tuutilainen, tuutilainen, / leväele lapsukainen." Lilius, joka oli "kuuluisa opista, puheentaidosta ynnä runolahjasta" 3 kirjoitti paitsi latinalaisia runoelmia myös häärunoja, joiden jatkoksi "Kehto-Runot" luontevasti sopiikin. Runossa on kirjoittajan papilliselle ammatille hyvin sovelias uskonnollinen pohjasävy. Jeesus on lapsen "kaunis kumppani", ja pienokaisen kehdon ääressä valvovat pyhät suojelijat.

Sata vuotta myöhemmin innosti sama aihe toista pappismiestä, Pietari Tickléniä, jonka kehtolaulu on päässyt kirjallisuudenhistoriaan myös siitä syystä - ja ehkäpä juuri siksi - että hänen runonsa tunsi Aleksis Kivi 4, joka myöhemmin "Sydämeni laulussa" loi unohtumattoman Tuonela-kuvitelmansa. Toimiessaan Oulussa konrehtorina -- lähinnä rehtoria oleva virka ylernmän alkeiskoulun opettajana - Ticklén julkaisi Oulun Wiikkosanomissa vuonna 1829 runon "Lapsellinen lapsenlaulu". Tuutija kehottaa lasta nukkumaan "levon ajalla", siis niin kauan kuin hänellä on siihen tilaisuus. Kohta on vanhempien tuki poissa, ja silloin "menet myrskyn vietävänä, / tuulen tuuditeltavana, / huolten henki purjehissa, / valehen

3 J. Krohn, Helmivyö suomalaista runoutta. Helsinki 1866. S. 33.

4 J. V. Lehtonen, Runon kartanossa. Johdatusta Aleksis Kiven runouteen. Helsinki 1928. S. 76. 
väki perässä". Taivaalla on kuitenkin tähti, "viitta kirkas kiiltämässä", joka ohjaa lapsen sinne, mihin isä ja äiti ovat jo ennen ennättäneet. Siellä onkin väsyneen hyvä olla, nukkua nurmen alla. "Siellä Tuoni tuudittaapi" ja siellä on toivo kerran herätä parempaan eloon. Siellä ovat myös virret viisaammat ja laulut paremmin laitetut. Taivaallisen elämän innoittunut ihannoiminen on tyypillistä papilliselle elämänkatsomukselle.

Perusvireeltään maallinen kehtolaulu on sen sijaan Yrjö Koskisen Suomettaressa vuonna 1857 julkaisema pikku runo "Vauva nukkuu", jossa runoilija sadunomaisin kuvitelmin antaa nuoren äidin tuutia pikku poikasen unen ukon vietäväksi. Korulausein ja hempein sanoin äiti kehottaa unen ukkoa kuljettamaan lapsen sulosaarille, soudattelemaan häntä venheessä ja tuomaan hänet lopulta takaisin oman äidin syliin. Runossa on iloinen ja veitikkamainen sävy ja siitä henkii voimakas elämänilo.

Aleksis Kiven "Sydämeni laulu" on jo vuosia ollut Suomen kansan lempiruno. Runosta kuultaa niin selvästi kuolemanikävöinti ja pyrkimys pois kavalasta maailmasta, että lukijoitten keskuudessa on syntynyt voimakas mielikuva Kiven omista synkistä elämänkokemuksista, jotka ovat saaneet runoilijan hakemaan rauhaa tuonpuoleisesta elämästä. Tutkijoittenkin keskuudessa on syntynyt "Sydämeni laulun" mielialasta varsin erilaisia tulkintoja. Viljo Tarkiainen toteaa "Sydämeni laulun" ja "Ikävyyden" todistavan, että "hänen kohtaloittensa (Kiven) yli oli jo aikaisin langennut varjo, jonka pimennoita ei keskipäivän kirkkauskaan pysty valaisemaan". 5 J. V. Lehtonen taas selittää, ettei "Sydämeni laulu" ole kuolemankaipuun runo ensinkään. Se on hänen tutkimustensa mukaan idyllinen haave. ${ }^{6}$ Koskenniemi sanoo runon sulkevan piiriinsä sekä kuoleman että elämän. Hänen tulkintansa mukaan lyyrillinen kuoleman melankolia, joka on niin keskeinen tässä runossa, on täydellisimmänkin maisen onnentunteen ikuinen seuralainen. ${ }^{7}$ Kiven kaunis kehtolaulu tarjoaa runsaita mahdollisuuksia runoilijan persoonallisten tunteiden tulkitsemiseksi, mutta toisaalta ilmeisten esikuvien löytyminen on myös omiaan vahvistamaan sitä mielikuvaa, että runo on jo niistä saanut

5 V. Tarkiainen, Aleksis Kivi. Elämä ja teokset. Porvoo 1915. S. 354.

6 J. V. Lehtonen, emt. s. 81 .

7 V. A. Koskenniemi, Aleksis Kivi. Porvoo 1934. S. 200. 
eräitä piirteitään. Ticklénin kehtorunosta voi Kiven Seitsemäss ä vel jeksessä olla peräisin Seunalan Annan kuvitelma maailman myrskyävästä merestä. Hän kertoo lapsilleen, että "moni purjehtija täällä on vaipunut sen merien ikuiseen kohtuun". Tuonela on Ticklénillä "meren mentävän takana, / tuolla puolen pahan salmen", Kivellä sinne päästään myös purjehtimalla ja se on sumean, tyynen järven rannalla.

Kantelettaren "Tuuti lasta Tuonelahan" on Kiven tutkijoitten mukaan ollut tuttu runoilijalle. 8 Kansanruno mainitsee Manalassa olevan suuren tuvan ja avarat majat. Seunalan Anna kertookin lapselleen Tuonelan tummasta kartanosta. "Sydämeni laulussa" lapsi tuudittelee "helmassa Tuonelan immen", kansanruno vain toteaa lapsen menevän "maan alle makoamahan, / Tuonen lasten laulatella, / Manan neitojen piellä'. Edelleen kansanruno kertoo Tuonen tuutusen olevan paremman ja Manan kätkyen kauniimman kuin maallinen kehto, Kivi taas saattaa lapsen kultakehtoon keinumaan.

"Sydämeni laulun" alkuaihe ja kiinnekohta on asetettu Kiven oman elämäkerran yhteyteen, nuorena kuolleen Agnes-sisaren varhaiseen poismenoon.9 Vuonna 1859 syntynyt "'Eriika" on kertomus nuoren tytön kuolemasta ja äidin murheesta. Siinä tavataan ensi kerran - nurmijärveläisenä muunnelmana - kansanrunon tuutulaulu vainajalle:

Levä rauhas kaunoiseni, Kohta pääset tuonen-tupaan.

Siel on seinät sammaleiset, Hieno hieta permannolla.

Eikös kelva lapsen maata, Illan kyljen kääntämätä, Olkapään ojentamata.

Kuten Lauri Viljanen mainitsee, kuvastaa viimeinen säe vielä varsin selvästi, kuinka tiiviisti Kivi seurasi kansanrunon poljentoa. 10 "Sydämeni laulussa". siitä poiketaan jo rohkeasti:

8 J. V. Lehtonen, emt. s. 82 . V. Tarkiainen, emt. s. 349 . Lauri Viljanen, Aleksis Kiven runomaailma. Porvoo 1953. S. 29.

9 Lauri Viljanen, emt. s. 28.

10 Lauri Viljanen, emt. s. 29. 
Tuonen lehto, öinen lehto!

Siell' on hieno hietakehto, sinnepä lapseni saatan.

Siell' on lapsen lysti olla, illan tullen tuuditella helmassa Tuonelan immen.

Runon rytmiin tulee kehdon keinuntaa, pehmeää heilahtelua edestakaisin. Siinä on myös elämänmyönteisempi, lämpimämpi sävy kuin kansanrunoissa, jotka pessimismissään joskus saattavat olla suorastaan tylyjä. Lasta ei toimiteta "lautojen sylihin" vaan "hienoon hietakehtoon".

1800-luvun lopulla kehtolauluja alkaa lyriikassa esiintyä yhä enemmän. J. H. Erkko, jonka runolliset lähtökohdat tunnetusti selitetään $K$ al evalan ja vielä enemmän $K a n t e l e t t a r e n$ pohjalla syntyneiksi, on kehtorunoissaan lähestynyt maallisemmin sävytettyjä kansanomaisia tuutulauluja. Kokoelmassaan U u sia r u n o el mi a, vuodelta 1885, hän julkaisi pienen laulelman "Tuutiessa". Siinä tuudittaja vaalii pientä valkeaista, liikuttelee Luojan lasta. Uskonnollisen värityksen alta kuultaa maallisen hyvinvoinnin ja vaurauden harras toivomus: "Tuudin lasta maan valoksi."

Vuosisadan lopulla myös Uno von Schrowe, Larin-Kyösti sekä Eino ja Kasimir Leino tunsivat tarvetta laulaa äitiyden onnesta. Ensiksi mainitun "Kehtolaulussa" ja Larin-Kyöstin "Tuutulaulussa" on paljon yhtymäkohtia Erkon runon kanssa. Myöskin eräiden kansanomaisten tuutulaulujen ajallinen hyvinvointi on ollut harras toiveiden kohde. Molemmissa runoissa tuudittajan tulevaisuuteen tähyilevä silmä näkee jo häitä vietettävän. Larin-Kyöstin runo on hauskoilla arkiaskareilla liitetty läheisesti kodin piiriin. Kissa, joka lapsen iloksi sieppaa hiirivarkaan, lienee lähtöisin kansanrunoista. Kissa on näet yleisesti lasten hyvä ystävä kansanomaisissa lasten loruissa. Se kiikuttaa kehtoa, jos tuudittaja väsyy, ja se leikkii uskollisesti lapsen kanssa.11 Sama viehättävä kodinläheinen ja lämmin tunnelma on myös Larin-Kyöstin "Lapin joulussa". Komsa kiikkuu hiljaa ja Lapin äiti laulaa lapselleen kultapulkasta, jossa pienokaisen on hyvä nukkua.

11 Elsa Enäjärvi-Haavio, em. kirj. s. 167. 
Viehättäyää kotoista idylliä hakee menneisyydestä se orpo tyttö, joka on pantu lapsen katsojaksi Kasimir Leinon runossa 'Huutolaistyttö kehdon ääressä". Pieni tyttö on menettänyt sekä isänsä että äitinsä ja laulaa nyt kehtolauluna murheellisen tarinansa. Runossa saattaa olla muistikuvia runoilijan lapsuudenkodista ja sen arkisesta elämästä. Hövelön talossa oli näet huutolaistyttö, joka oli erikoisen hyvä tarinankertoja, ja nuoret Lönnbohmit olivat hänen innokkaita kuulijoitaan. 12

Legendarunojen lempeä neitsytäiti on lapsensa tuudittajana Eino Leinon "Marjatan laulussa". Kansanuskon kylpyä hakevan synnyttävän naisen tarinaan on runossa sulautunut kristillinen Betlehemin seimi ja tähti. Kansanomaisista tuutulauluista on kotoisin myös maininta Tuonen tulosta lapsen kehdon ääreen, nähtävästi myös lapsen nimittäminen nurmilinnuksi. Se, että Leino on kuvitellut kauniin kehtolaulunsa juuri Marjatan tarinaan, on johtolanka hänen persoonallisiin tunteisiinsa. Marjatta, Maaria, yleensä.suomalainen Madonna-aate on haltioittanut häntä läpi koko hänen tuotantonsa. Marjatta-symboliin pohjautuu ikään kuin mystillinen uskontunnustus, jolla on yhtymäkohtia koko hänen parhaimpaan lyriikkaansa. Tähtitarhassa on runo "Marjatan tähdet", jossa runoilija uskoo Marjatan tähdillä, tietäjän tähdillä, olevan valoa tuovan vaikutuksen koko maailman elämään. "Sydänyön laulussa" hän taas huudahtaa haltioituneesti:

Maaria, Maaria, ah emo Luojan!

Löysin sun luonasi turvan ja suojan, näin sinut ihmisten joukossa täällä, lemmin ja lauloin pilvien päällä.

H elkavirsien toisessa sarjassa palataan tähän aiheeseen runossa "Marjatan poika".

Koska Marjatta-aihe on Leinon lyriikassa ollut niin keskeinen ja hedelmöittävä aihe, on lupa pitää sitä hänen omassakin elämässään läheisenä. Seuraava kappale runoilijan omasta kirjeestä luonee valoa hänen käsitykseensä korkeimmasta elämänihanteesta: 'Minun täytyy rakkaudessa saada tuntea jotakin mystillistä, legendaarista, samalla raamatullista ja kalevalaista tähtitaivasta, jos sen mieli

12 L. Onerva, Eino Leino. Runoilija ja ihminen. I. Helsinki 1932. S. 26. 
olla mitään rakkautta mielestäni. Minun täytyy saada tuntea jotakin pyhää, korkeata kuin kirkko ja samalla kotoista kuin seimenlämmin." 13

Lämpöä, nimenomaan naisellista lämpöä huokuu jo ensimmäisestä Marjatta-runosta, alun kolmannellakymmenennellään olevan nuorukaisen kehtolaulusta. Vaikka runo onkin paikoin dramaattinen ja kiihkeä, sen pohjavireenä on hyräilevä lyyrillisyys:

Keinutan kehtoa, laulatan lasta

vaulassa vemmelpuun.

Nukkuos tähtiä katselemasta, vaipuos kuusia kuuntelemasta, uinuos äitisi lauleluun, keinuhun vemmelpuun.

"Marjatan laulu" aloittaa myös niiden kehtolaulujen sarjan, joissa äidin ja lapsen suhde on muuttunut persoonallisemmaksi kuin kansanrunoissa ja osittain vanhan taidelyriikkammekin tuutulauluissa. Kansanrunon äiti kohdistaa harvoin laulunsa välittömästi itse lapselle, joku 'Nuku, nuku, nurmilintu" on poikkeus. Tavallisesti tuudittaja osoittaa sanansa jollekin toiselle, kokonaan ulkopuoliselle tai hyräilee yksikseen. Lapsen nukuttaminen todetaan myös aivan yleisesti, kuten runoissa "Minä laulan lapselleni", "Minä tuuin tuttuani" tai "Tuuti, tuuti poikalasta". Jos sanat runon loppupuolella osoitetaankin tuuditeltavalle itselleen, ne ovat useimmiten varoittavia: "Ellös vainen, tyttöparka, / huolta huoville pitäkö, | mieltä miekankantajalle." Ei Aleksis Kivenkään "Sydämeni laulu" ole lapselle suoraan osoitettu, vaikka äidin hellä huolenpito onkin niin näkyvänä runossa. Leinon Marjatta-äidin mukana tulee äiti ja lapsi -suhteeseen persoonallisempi sävy äidin kertoessa lapselle omista vaikeuksistaan. Ihmiset ovat tylyjä ja kovia, köyhän ihmisen osa on katkera. "Pysty on kulkea pyytäjän tie / - sulleko loivempi lie?"

Leinon "Marjatan laulun" läheinen sukulainen on Oiva Paloheimon "Neitsyt Maarian kehtolaulu" - onpa syytä arvailla, että Leinon runo on ollut alitajuisena muistikuvana Jeesus-lapsesta kertovan runon svntyessä. Säkeet "Miksi et nuku? yhä vain / ojennat

13 L. Onerva, emt. II. S. 22. 
pientä kättäs" tuovat etsimättä mieleen Leinon sanat "Miksi et nuku, oma kukkani, rukkani?" Kylmyys ja pakkanen ovat myös yhteisiä molemmille runoille. Paloheimo vie kuitenkin runonsa lähemmäs Raamatun kertomusta puhuessaan juhtien heinistä ja ristiinnaulitsemisesta. Paloheimon madonnanpalvonta tulee esille monessakin hänen runossaan erikoisen lämpimässä ja kauniissa muodossa. Tämä toistuva teema hänen lyriikassaan kumpuilee runoilijan omista katkerista lapsuuden elämyksistä ja on monine sivuvivahduksineen tullut hänen taiteelleen erikoisen hedelmälliseksi.14

Yhtä sattumanvarainen kuin kansantarinassa Marjatan äidiksi tulo on elämän alkaminen myös V. A. Koskenniemen runossa "Balladi virran rannalta". Mutta vaikka lapsen syntyminen onkin ollut sattuma, on äidinrakkaus syvää ja koko elämän täyttävää. Jos Leinon "Marjatan laulussa" on perinnäisen Maaria-kultin antamaa juhlallista ja korkean pyhää Jumalan äidin palvontaa, täytyy sanoa, että Koskenniemen balladissa nuoren naisen osa on inhimillisesti katsoen vain pieni ihmiskohtalo. Tuosta pienestä naisosasta säteilee kuitenkin niin paljon harmonista, Iuonnonvaraista luonnollisuutta ja syvää elämän kunnioitusta, että runo kasvaa jalon ja kypsän elämänlämmön suureksi ylistyslauluksi. Balladissa nainen istuu vertauskuvallisen virran rannalla, elämän virran rannalla ja tuudittelee polvillaan lasta, jolle hän hyräilee kehtolauluna lyhyen rakkautensa tarinan. "Outo, armas, uupunut mies" on eräänä kevätiltana löytänyt tien hänen kammioonsa. Kohtalokas rakkauselämys on koruttomasti kerrottu:

\section{Nukkui hän yön minun vierelläni, kevätyön ainoan elämäni. \\ Kun minä aamulla heräsin, tyhjän ma syliini tapailin.}

Aamulla miehen venhe kulkee jo kaukana. Virta on tuonut sen tullessaan ja virta vie sen taas mukanaan. Nuoressa naisessa on jotakin ikuisesti naisellista, tyyntä, pehmeää ja alistuvaa, ja hän ottaa kohtalonsa kiitollisena vastaan sellaisena kuin se tulee. 'Lapsi, en lausunut tuomion sanaa, / vielä sun isäsi venheen vanaa, / sieluni seuraa siunaten." Elämän aamu säteilee tytön sylistä, mutta se joh-

14 Toini Havu, esip. Oiva Paloheimon Runoihin. S. XIV. 
dattaa ajatukset myös jo elämän iltaan. Tuonela-ajatus värähtää naisen sanoissa hänen kehottaessaan lasta nukkumaan ja keräämään voimia, jotta tämä jaksaisi taivaltaa pitkän matkan elämän iltaan saakka.

Koskenniemen balladista huokuu syvästi suomalainen tunnelma, joka antoi ominaisleiman myös Leinon 'Marjatan laululle". Leinon runossa se on eräissä yksityisissä sanoissa, Koskenniemellä se on maisemassa. Eräänlainen viileä rauhallisuus on myös tyttömadonnan suomalainen piirre.

Kaikkea paikallistunnetta vailla on sen sijaan Kaarlo Sarkian "Kehtolaulu". Sen yllä väreilee aineeton kuulaus eikä maisemaa ole ollenkaan. Vastakohtina ovat maailma ja avaruus. Runo liittyy kiinteästi kehtolaulujen Tuonela-kuvitelmien ketjuun. Mutta tässä ei enää puhuta paikallisesti tarkoin määrätyistä Manan majoista, ei Tuonelan kartanosta. Vaikka runoilija puhuukin "maaemon kehdosta", johon lapsen on paras nukkua, koska "raskas on oppia askelten taito", hänen Manalansa on avaruudessa, tähtien heijassa. Elämisen paino tuntuu muuten olevan usein toistuvana ajatuksena myös uudemmissa kehtolauluissa. "Marjatan laulussa" pyytäjän tie on pysty kulkea, ja Koskenniemen balladissa "pitkä on taival kulkijan, / elämän aamusta iltahan".

Sarkian kehtolaulussa Tuonela-kuvitelma on runollisen hohteen ympäröimä. Ikuista unta ympäröi lumoava hohde. Runoilijalla ei enää ole jäljellä elämän illuusiota, mutta sitä vahvempana unen ja kuoleman illuusiot.15 Tuonpuoleinen elämä näyttää niin houkuttelevalta, että runossa on suorastaan elämästä poispäin kohdistuva pyrkimys. Kosmiset näyt kiehtovat runoilijan silmää, ja kodin kehdosta, jossa pieni lapsi lepää, tulee tähtien liekku. Pienestä pisteestä avautuu huikaiseva näky suureen maailman tuutuun, joka keinahtelee "suvesta talveen ja talvesta kesään". Syystä onkin sanottu Sarkian kehtolaulun olevan yhden ihanimmista kehto-hautalauluista, mitä milloinkaan on kirjoitettu.16 Se karkottaa jopa kuoleman synkkyyden olemattomiin. Siinä ei kertaakaan mainita sanaa kuolema tai S. 483 .

1.5 Unto Kupiainen, Suomalainen lyriikka Siljosta Sarkiaan. Porvoo 1948.

16 V. A. Koskenniemi, arvostelu Kaarlo Sarkian Unen kaivosta. Kootut teokset IX. Porvoo 1955. S. 134. 
tuoni. Ei puhuta "poispääsemisestä" tai "ihanammasta elosta", puhutaan vain nukkumisesta ja unesta. Jokainen säkeistö alkaa samalla verbillä ja sillä on arvaamattoman suuri tehovoima runon yleisen mielialan syntymisessä. Sana "nukkuos" melkein houkuttelee pyrkimään "tähtien heijaan". Sarkian kuvitelma kuolemantakaisesta elämästä "tuulien pesässä" ja "tähtien liekussa" saa aikaan samanlaisen heijaavan mielikuvan lukijan ajatuksissa kuin Kiven kultakehto, jossa lapsen on lysti olla. Sarkian ja Kiven runoissa yksityisen ihmisen merkitys suuressa maailman keinussa sen sijaan on poikkeava. Kivellä ihminen ja maailma ovat tavallaan vastakkaissuhteessa keskenään ja yksityisen ihmisen elämään tuo suurta helpotusta se, että kavala maailma jää kauas taakse. Sarkialla sen sijaan yksi ihminen on vain mitätön osa suuressa kohtalon keinussa, eikä häntä jäädä kaipaamaan :

Nukkua saat sinä tuulien pesään, unestas ei meno päivien muutu. Suvesta talveen, talvesta kesään, mahtava keinuu maailman tuutu.

Viljo Kajavan "Kehtolaulu" on äidin yksinpuhelu lapselleen Eino Leinon ja Koskenniemen runojen tapaan. Viehättävät kotoiset kuvat, tuleentuvat ruispellot ja hämärän tuvan hiljaiselo taas olivat tuttuja jo Larin-Kyöstin tuutulaulussa. Larin-Kyöstin runon veitikkamaisesta sävystä sen kuitenkin erottaa surumielinen kaipaus ja hiljainen, alistuva tyytyminen elämään. Äiti kertoo lapselleen, että isä ei enää koskaan voi palata heidän luokseen, he ovat jääneet kahden. Elämä jatkuu kuitenkin eteenpäin, ja äiti toivoo lapsestaan miehen työn jatkajaa. Pellot eivät saa jäädä autioiksi ja maa viljelemättä.

Einari Vuorelan lyriikasta löytää myös lapselle omistettuja säkeitä. Pieni laulelma "Tuutulaulu" asettaa maailman kylmyyden ja lapsen turvallisen unen vaikuttaviksi vastakohdiksi. On mielenkiintoista huomata, että päinvastoin kuin kansanlauluissa äiti toivottaa lapsensa Tuonen tuville pois tylystä maailmasta, Vuorelan tuutulaulun laulaja pitää koko maailmaa suurena kalmistona, josta lapsen on parasta paeta unien maailmaan. Eräs toinen Vuorelan tuutulaulu sisältää saman teeman. "Äidin laulu" on laadittu tunnetun kansanballadin "Veljen surmaajan" tapaan kysymysten ja vastaus- 
ten muotoon. Äitiä pelottaa siinäkin "pahan pimeä aita" ja hän kehottaa lastaan pyrkimään "valkeaan unelaan". Lapsi on runossa tehty varhain kehittyneeksi, vaikka äiti sanoo häntä vauvaksi. Runo tuo mieleen etäisesti jotkut kansantarujen henkilöt, jotka jo kätkyessä pystyivät hämmästyttäviin voimatekoihin, vaikka tässä on lähinnä kysymys lapsen henkisestä kypsyydestä. Pikkuinen makaa kätkyessään ja tekee kysymyksiä äidille, joka lopulta tuskastuu tuudittamiseen: "Vauva — jo valkeaan Unelaan harhaa!"

Kehtolaulujen maailma ei ole ollut avoinna vain lyyrikoille. Myös proosan mestarit ovat tunteneet tarvetta laulaa kehdossa makaavalle lapselle. Ilmari Kiannon lapselleen sorvaamissa tuutulauluissa on kuitenkin enemmän kirjailijan oman lauluntekotaidon ylistystä kuin harrasta halua viihdyttää lasta. "Tuutulauluja"-sikermä, verraten pitkä kalevalaiseen mittaan laadittu runosarja, alkaa hyvin kuvaavasti: "Nuku, nuku, poika kulta, / äiti sulle laulun laulaa, / isä itse laulun laittoi ..."

Mieslyyrikkojen kehtolauluista kuultaa kuitenkin aivan yleisesti harras kunnioitus elämän mystillistä alkua, lapsen syntymää kohtaan. Ihmeteltävän uutterasti he ovat myös viljelleet runouden tätä sarkaa. Tuntuisikin näin ollen oudolta, jos naispuoliset runoilijamme olisivat tyystin sivuuttaneet äiti ja lapsi -aiheen, joka ikään kuin luonnostaan tuntuu lankeavan juuri heille. Varsinaisia kehtolauluja on kuitenkin yllättävän vähän. Runot ovat suureksi osaksi lapsensa myöhempää kehitystä seurailevan äidin onnesta kimmeltäviä runoja. Xidin osa on naislyyrikolle toisella tavalla omakohtainen ja joskus hyvinkin subjektiivisista elämyksistä lähtöisin. Lisäksi elämyspohja on laajempi. Monet runoista onkin kirjoitettu jo ennen lapsen syntymää. Suomalaisen lyriikan naisrunoilijoista on äitiyden luova elä.mys innoittanut erikoisesti Elina Vaaraa, Aale Tynniä ja Aila Meriluotoa.

Elina Vaaralla on äiti ja lapsi -runoja enemmän kuin kenelläkään muulla lyyrikollamme, onpa hänellä kokonainen kokoelmakin runoja, joissa on tämä aihe keskeisenä motiivina. Hänen runoissaan on kuitenkin usein tavanomainen äiti-kultti syrjäyttänyt persoonallisen suhtautumisen aiheeseen. Äidilliset tunteet saavat liian kiiltävän ja korean ilmaisun. "Kehtolaulussa" on äidin suojeleva hellyys keskeisenä runossa. Äiti hoivaa pientä lastaan ja puhuu hänelle viihdytellen ja kuin houkutellen häntä uneen: 
Unessa on polut, tiet -

satoi monta yötä.

Ethän vainen pelkää, pieni lapsi?

Kun sa lähdet kerran, viet

sydämeni myötä.

Paina pääsi helmaan, tummahapsi.

Aila Meriluoto liitti jo esikoiskokoelmaansa herkän kehtolaulun, joskin hänen elämyksensä äiti ja lapsi -suhteessa syventyivät myöhemmissä runoissa. "Yölaulussa" on hellä, suojeleva sävy ja sitä keventävät vanhat, sadunomaiset aiheet. Tuudittaja keinuttaa lasta nukkumaan. Sisällä on lämmintä ja unenraukeata, vaikuttavana vastakohtana on ulkona tuulinen yö:

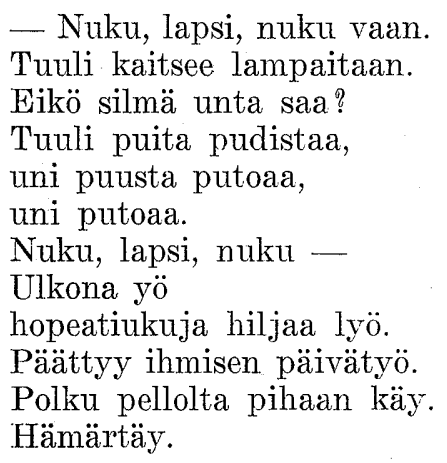

Äiti kertoo lapselleen, miten tuuli kaitsee avaruudessa pilvilampaitaan ja illan tullen ne ajetaan navettaan. Lammaskuvitelma tuo mieleen jo melkein kansanlauluksi muuttuneen Larin-Kyöstin runon "Pilviä kaitsemassa". Siinäkin on sama leikkivä asetelma. "Pilvet on valkeita lampaita, / ne ajan minä taivahan tarhaan." Meriluodon runossa tuulen humina talon ympärillä saa ihmisen tuntemaan itsensä mitättömäksi luonnon mahtien rinnalla: "Outo on taivas, suuri on maa." Runon filosofinen loppumietelmä tukee samaa ajatusta: "Vähä on yössä ihmisen suku." L a s i m a a l a u k s e n kehtolaulu on Aila Meriluodon runoudessa vielä pehmeä ja lämmin, paikoin koristeellinenkin ja kuvarunsas. Toisen kokoelman äitielämys lähtee jo karun elämänläheisyyden pohjalta.

Kehtolauluissa kuvastuu myös elämän jatkuvaisuus. Niin kauan kuin on elämää maan päällä, tulee runoilijoitten kokoelmissa ole- 
maan kehtolauluja. Olavi Siippainen on runossaan "Äiti" tuntenut sen suurena elämyksenä katsellessaan nuoren naisen tuudittelevan pienoistaan uneen:

Äiti lastaan tuutien syliin unen pehmoisen näky suuri, kuolematon, päällä maan:

halki vuosituhanten äidit lastaan tuutien samoin laulaneet on iltaan tummuvaan!

Lyriikkamme kehtolaulujen maailma on hyvin laaja-alainen. Siihen sopii, jos aihe käsitetään laveasti, hyvinkin monia muunnelmia tästä aiheesta. Voidaan mainita useita runoilijanimiä, joille keinuvan kehdon heilahdus on ollut lyyrillisen innoituksen lähde. Aino Kallaksen "Viimeinen kehtolaulu" on, kuten. nimestäkin näkyy, enemmän hauta- kuin kehtolaulu. Yksin jäänyt äiti pelkää lastensa palelevan haudassa, ja hän "riistää tulen rinnastaan ja tuskan povestaan" lastensa lämmittämiseksi. Aaro Hellaakosken huumorinkyliäinen ja onnekas lapsirunous on kehdon ääressä syntynyt. Hilja Haahdella ja L. Onervalla on joitakin pieniä tuutulaulun luontoisia pikku runoja. L. Onerva kuvittelee runossaan "Keinutan kaikua" omalaatuisella tavalla tuudittelevansa tunteensa lasta, lauluaan. Runolla on rytmillisesti ilmeisiä yhtymäkohtia Eino Leinon "Marjatan laulun" kanssa. Niin ikään Helvi Hämäläinen, Heikki Asunta, Tivo Härkönen, Otto Manninen, Yrjö Kaijärvi, Antero Kajanto ja eräät muut vähemmän tunnetut runoilijamme orat pikku laulelmissaan viihtyneet hetken keinuvan kehdon äärellä.

Runoutemme tunnetuimmilla kehtolauluilla on vankka pohjansa suomalaisessa kansanrunoudessa. Ne ankkuroituvat paljon kiinteämmin tuntemattomien äitien sepittämiin lauluihin lapsilleen kuin runoutemme muut äiti ja lapsi -runot. Muita lapsirunoja ilmestyykin lyriikkaan verraten myöhään. Lapsen merkitys lyyrillisenä motiivina on näet tuntuvasti kasvanut vasta sen jälkeen, kun yhteiskunnan lapseen kohdistama mielenkiinto on lisääntynyt.17 Kansanrunoista on kehtolauluissamme säilynyt katkeamattomana aina nuorimpaan tässä esitettyyn runoon asti ajatus maallisen elämän epävakaisuudesta ja sen mitättömyydestä Tuonelan, Manalan, kosmisen S. 125 .

17 Kyllikki Vehanen, Lapsiaiheita suomalaisessa lyriikassa. Valvoja 1947. 
avaruuden tai luonnonkaikkeuden rinnalla. Vaikka Tuonela-kuvitelma ei kaikin kerroin selvästi esiinnykään tuutulauluissa, on ihmiselon katoavaisuus ja maallisen vaelluksen raskas taivaltaminen usein näkyvänä aiheena kehtolauluissa. Alkavan elämän läheisyydessä tulee tietenkin vaistomaisesti tuudittajan mieleen pelko lapsen kykenemättömyydestä selviytyä yhteiskunnan hänelle asettamista vaatimuksista, koska pikkuinen näyttää niin avuttomalta kätkyessään.

Kehtolaulujen rytmi on yleensä rauhoittavaa, joskus hyräilevää ja pehmeää. Kiintoisa huomio on se, että niissä usein puhutaan venheestä, joka keinuttaa lasta. Venheen keinuminen saa aikaan rytmillistä liikettä, joka kuvastuu runoissa ja soudattelee lapsen uneen.

Varsinkin naislyyrikkojen kehtolauluissa on erikoisen selvästi havaittavissa se, että äiti haluaa suojella lasta. Toisinaan runoissa on unenomaista hämäryyttä ja melankolista surumielisyyttä, joka vaikuttaa suggeroivasti ja houkuttelee tällä tavalla lapsen uneen. Usein esiintyvä "elon lain" kohtalonomaisuus ei kuitenkaan riistä tuudittajalta sitä tunnetta, että hän lapsen läheisyydessä on saavuttanut jotakin ainutkertaista elämän suuresta rikkaudesta ja täyteläisyydestä. Lapsen pienet kädet ja kirkkaat silmät vangitsevat tuudittajan niin kokonaan, että hän tuntee koko elämän olevan käsissään saadessaan lapsen kautta tuuditella tulevaisuutta.

\section{KerTtu Tanner: Das Wiegentied in der finnischen Lyrik}

Die Geschichte der Wiegenlieder in unserer Lyrik greift so weit in die Vergangenheit zurück wie ein Verfolgen unserer Dichtung überhaupt möglich ist. Im alten Versmass abgefasst sind die Wiegenlieder, womit die Mütter vormals ihre Kinder in den Schlaf sangen und ihnen zärtliche Kosenamen gaben. Hie und da enthalten die Wiegenlieder Wünsche zeitlichen. Wohlergehens. Die Mutter, die ihrem Kind die Annehmlichkeiten weltlichen. Wohlstands und eine gesicherte Zukunft erhofft, schliesst auch die Möglichkeit nicht aus, dass das Kind die Stütze ihres Altertums werden könne. In einigen Fällen wünscht die Mutter, es möge dem Kind beschieden sein, in "die Hütten des Todes" (manan majoille, Tuonen kartanoille) einzukehren, weil sie fürchtet, das Kind würde die Härte der Menschen allzu stark erfahren, ihm würde allzuviel Unglück hegegnen. In besonders schöner und poetischer Form erscheint die Nähe des Todes in dem kleinen Wiegenlied "Tuuti lasta Tuonelahan" (Wiege das Kind hinüber ins Totenreich). Der Totenreich-Gedanke dieses schönen Wiegenliedes ist durch die Jahrhunderte hindurch aus einem Wiegenlied ins andere bis in die heutige Dichtung übertragen worden. 
Die Wiegenlieder des 16. und 17. Jahrhunderts erinnern sowohi im Versmass als auch inhaltlich sehr an die vollsstümlichen. Wiegenlieder. Gegen Ende des 18. Jahrhunderts gehen die Dichter auch in ihren Wiegenliedern vom Versmass des Volksliedes ab. Zu den schönsten Wiegenliedern unserer Dichtung zählen wir das Gedicht "Sydämeni laulu" (Lied meines Herzens) von Aleksis Kivi. Die Mutter wiegt ihr Kind und singt ihm vom Hain des Totenreichs, wohin sie es mit ihrem Lied begleitet, damit es in der goldenen Wiege schlafe. Eine Berührung mit der alten Wiegenliederdichtung ist unverkennbar; soviel bekannt, war das Volkslied "Tuuti lasta tuonelahan" dem Dichter nicht fremd.

Am Ende des 18. Jahrhunderts wurden Wiegenlieder von u.a. Uno von Schrowe, Larin-Kyösti sowie den Brüdern Eino und Kasimir Leino gedichtet. Das Gedicht "Marjatan laulu" (Marjattas Lied) von Eino Leino zeigt engste Berührung mit dem Todesgedanken der volkstümlichen Wiegenlieder. Die milde Jungfraumutter der Legenden wiegt darin ihr Kind, und das Gedicht enthält sowohl volkstümliche Glaubensvorstellungen als Bestandteile der Legendengedichte. - Auch V. A. Koskenniemi bringt das Wiegenlied der einsamen jungen Mutter in unsere Lyrik, indem er in seinem Gedicht "Balladi virran rannalta" (Ballade am Ufer des Stromes) eine Mutter am Ufer des sinnbildlichen Lebensstromes ihr Kind wiegen lässt. Der Gedanke an ein Totenreich zittert auch in diesem Gedichte nach, indem das Mädchen ihr Kind auffordert, lange zu schlafen, damit es Kräfte sammle für den langen Weg bis zum Lebensabend.

Auf gutem Grund hat man Kaarlo Sarkias "Keltolaulu" (Wiegenlied) das schönste Wiegen- und Grablied genannt, das je geschrieben wurde. Das Gedicht ist von einer immateriellen Klarheit, zudem ist darin von keinem genau lokalisierten Totenreich mehr die Rede. Indem Sarkia sich vorstellt, das jenseitige Leben existiere "in der Schaukel der Sterne" und "in der Heimat der Winde", verliert das Gedicht die düstere Stimmung der Todesfurcht. Der Dichter spricht ja auch nicht vom Sterben, sondern vom Schlafen. Zu erwähnen sind noch u.a. Heikki Asunta, Einari Vuorela, Viljo Kajava und Oiva Paloheimo, die auch Wiegenlieder gedichtet haben. Sie haben in ihrer Lyrik das glïckliche Vor-sich-Hinsingen der Mutter beim. Einschläfern ihres Kindes vielfältig zum Ausdruck gebracht.

Die Wiegenlieder der weiblichen Lyxiker beruhen natürlich auf subjektiveren Lebenserfahrungen als die Schlaflieder der männlichen Dichter und zeigen eine oft sehr persönliche Einstellung zu dem Los der Mutter. Das schöpferische Erlebnis der Muttersehaft hat vor allem auf Elina Vaara, Aale Tynni und Aila Meriluoto anregend gewirkt. Bei Elina Vaara finden wir mehr "Mutter und Kind"-Gediehte als bei irgend einem unserer Lyriker. In ihren Gedichten verdrängt jedoch der herkömmliche Mutterkultus die persönliche Einstellung zum Thema.

Der Gedanke an die Vergänglichkeit des menschlichen Lebens und die Nichtigkeit des irdischen Daseins gipfelte in den Totenreich-Vorstellungen der Gedichte und ist aus unseren Volksliedern über die Wiegenlieder bis in unsere neueste Lyrik vorgedrungen. Auch die Kontinuität des Lebens kommt in den Wiegenliedern zum Vorschein. Solange es Leben auf Erden gibt, werden die Dichter immer wieder zu dem Thema des Wiegenliedes greifen. 